\title{
A hazai vízkészlet-gazdálkodási gyakorlat változásainak bemutatása a 20. századtól
}

\section{Changes in Hungarian Water Management Planning in the $20^{\text {th }}$ Century}

A hazai vízkészlet-gazdálkodási szakág gazdag múlttal rendelkezik, a 20. században nagy fejlődésen ment át. Vízmérlegek készítésével a század közepétöl kezdtek el foglalkozni a szakemberek, azóta pedig számos kiadvány született a témában. A számítási módszerek több eleme változott ebben az időben, viszont maradt néhány alap, ami a kezdetek óta állandó. Jelen cikkben áttekintem a szakág magyarországi fejlödését, röviden értékelem a módszereket, valamint felvázolom a jövőben várható fejlődés irányát

Kulcsszavak: vízkészlet, keretterv, évkönyv, vízmérleg, modellezés

The Hungarian water resources management has a long history. In the $20^{\text {th }}$ century it has improved greatly. The water engineers have been making water balances since the middle of the century and they have also been publishing a lot on this topic. The methods have been changed, but the main elements remained the same, just like in 1965. In this article, the author reviews the history of Hungarian water resources management, analyses the methods and delineates the possible future changes.

Keywords: water resources, framework, almanac, water balance, modelling 


\section{Bevezetés}

A vízkészlet-gazdálkodás a legfiatalabb klasszikus vízügyi szakág, amelynek jelentőségét a 20. század második felében, a vízügyi igazgatás államosítása után ismerte fel az ágazat, korábban főként a vizek kártételeivel szemben való védekezésre helyezték a hangsúlyt [1]. Fogalmára számos definíció született Magyarországon, ezek nagy része jól kifejezi annak lényegét is. A vízkészletekkel való gazdálkodás során először meg kell határozni egy vízgyújtő vízkészleteit valamilyen módszerrel, majd ezeket össze kell vetni a társadalmi igényekkel.

A fenti egyszerűsített meghatározásból látszik, hogy a feladat elvégzésére, azon belül föként a vízkészletek meghatározására több módszer is alkalmas, és annak elvégzése a technológia fejlődésével más-más irányba haladhat. A vízkészlet-gazdálkodás az 1970-es évek elejére ért el fejlődésének arra a fokára, amikor szükségessé vált a tervszerü, komplex gondolkodás a témában [2], ebben az időszakban több tankönyv is készült az akkori vízügyi mérnökök képzésének elősegítésére.

Jelen cikk célja a hazai vízkészlet-gazdálkodás történetének áttekintése, fejlődési irányainak és módszereinek vázlatos bemutatása és a jövőben várható változások felderítése.

\section{A magyar vízkészlet-gazdálkodás rövid történeti áttekintése}

Az 1900-as évek elején a vízkészleteket szinte korlátlanul rendelkezésre álló természeti kincsnek tekintették, ezért ebben az időszakban Magyarországon az ár- és belvízelöntések elhárítása jelentette a prioritást a vízgazdálkodásban. Az évszázad első felében már távlati terveket és beruházási programokat készítettek a szakemberek $(1908,1929)$, azonban ezek a dokumentumok nem a vízkészletekkel való gazdálkodás elvégzését helyezték előtérbe [3].

Érdemes ebből az időszakból Sajó Elemér munkásságát kiemelni, aki a két világháború közötti időszak vízügyi szolgálatának kiemelkedő vezetője volt. Fő műve, az Emlékirat vizeink fokozottabb kihasználása és újabb vízügyi politikánk megállapitása tárgyában 1931-ben jelent meg, a Magyar Tudományos Akadémia Chorin Ferenc-díjjal jutalmazta. Ebben a munkájában évtizedekre kijelölte az országban szükséges vízügyi fejlesztéseket. Életének utolsó éveiben foglalkozott az Alföld öntözési gondjainak megoldásával, a szikes területek problémáival és a Duna-Tisza-csatorna kérdéskörével, amelyeknek már egyértelmü a vízkészlet-gazdálkodással való kapcsolata [4].

A második világháború után 1948-ban megtörtént a vízügyek államosítása, így az állam feladatává vált minden vízgazdálkodási tevékenység. Ekkor megalakult az Országos Vízgazdálkodási Hivatal és területi szervei, a vízgazdálkodási körzetek és kirendeltségek. 11 minisztérium képviselőjéből létrejött az Országos Vízgazdálkodási Tanács is. 1953. október 1-jén alakult meg az önálló vízügyi államigazgatás, amellyel megkezdte müködését az Országos Vízügyi Főigazgatóság és 11 vízügyi igazgatóság [1].

A vizek hasznosításának hatékonyságát tủzte ki célul az 1954-ben kiadott első Országos Vízgazdálkodási Keretterv, azonban ez nem volt széleskörüen elterjedt az ágazatban és a tervezett megvalósítás ütemezése sem volt végrehajtható. A vízmérlegre 
támaszkodó vízkészlet-gazdálkodás szükségessége 1949-ben merült fel először az iparvidékeken kialakuló vízellátási nehézségek megoldása érdekében, így ez a terv már tartalmazott átfogó jellegű vízmérleget. A jelentősebb helyi problémákra választ adó vízmérlegek szerkesztésére 1959-ben került sor [3].

A hazai vízkészlet-gazdálkodás éves eredményeit és módszereit a Vízgazdálkodási Intézet által 1960-tól kiadott Vízkészletgazdálkodási Évkönyv sorozat kötetei tartalmazták. Ezek a kiadványok sem csak vízkészlet-gazdálkodással foglalkoztak, azonban a hangsúly erre a szakágra tevődött.

1965-ben adták ki a második Vízgazdálkodási Kerettervet, amely országos és 13 területi egység terveit is tartalmazta külön kiadványként. A keretterv általános tájékoztatója a következő gondolatokkal indul: „Korábban a víz a korlátlanul rendelkezésre álló természeti javak egyikének tűnt. A népszaporodás, a nagyobb városok kialakulása, az ipari és mezőgazdasági termelés fejlődése, a kultúra előrehaladása a vízigények olymérvű növekedésével járt, amelyet a természetes vízkészlet a Föld egyes területein már nem elégít ki. A száraz években vagy évszakokban Magyarországon is mindinkább jelentkezik a vízhiány, ugyanakkor nedves években, vagy csapadékos évszakokban az ország területének jelentős részét árvíz- és belvízelöntések veszélyeztetik" [3: 7.].

Látható tehát, hogy felismerték ebben az időszakban a vízkészletekkel való hatékony gazdálkodás fontosságát. Az 1965-ös keretterv 19 fejezete közül a második a vízkészletek számbavételéről szól, a tizenhetedik pedig a területi vízmérlegről.

Az 1970-es évekre jutottak el az országban a vízkészlet-gazdálkodás fejlődésének arra a fokára, amikor szükségessé vált a tervszerü, komplex gondolkodás [2]. Ebben az időszakban számos egyetemi tankönyv, müszaki tájékoztató született a témáról, olyan szerzőktől, mint Dégen Imre, Domokos Miklós vagy Börzsöny Dénes.

1984-ben adták ki a harmadik Országos Vízgazdálkodási Kerettervet, amelynek felépítése hasonló volt a korábbihoz és itt is hangsúlyos szerepet kapott a vízkészletgazdálkodás témaköre. Meghatározták a hasznosítható vízkészleteket a nagyobb vízgyüjtőkre, valamint az igényekkel összevetve vízmérleg is készült [8].

A Vízkészletgazdálkodási Évkönyveket 1988-ig adták ki, 1993-2010-ig pedig megjelent Magyarország vízkészleteinek állapotértékelése a Környezetvédelmi és Vízgazdálkodási Kutató Intézet (VITUKI) kiadásában.

Szemléletbeli változást hozott az Európai Unió 2000-ben kiadott Vízkeret Irányelve (a továbbiakban: VKI), ennek 25. pontja szerint: „A vizek állapotának leírására minőségi, és, ahol az környezetvédelmi szempontból lényeges, mennyiségi szempontból közös fogalmakat kell meghatározni. Környezeti célkitüzéseket kell meghatározni annak biztosítására, hogy a Közösségben mindenütt elérhető legyen a felszíni és a felszín alatti vizek jó állapota, és hogy a vizek állapotának romlása közösségi szinten megelőzhető legyen" [6]. Előtérbe helyeződött tehát a vizek minőségének kérdése azok mennyiségi leírásával szemben. A VKI előírásait alapul véve Magyarország 2009-re elkészítette első Vízgyüjtő-gazdálkodási Tervét (VGT), majd 2015-re felülvizsgálta azt. Jelenleg a harmadik VGT-terv elökészítése zajlik, ahol a tervek szerint hangsúlyosabb szerepet kap a vizek mennyiségi értékelése is.

A számítástechnika fejlődésével egyre nagyobb szerepet kaptak a vízügyi ágazatban a különböző számítógépes modellek, ennek megfelelően a vízkészlet-gazdálkodásban is elindult 2016-ban egy átfogó modellezési célkitűzés vízmérlegek készítésére [5]. 


\section{A magyar vízkészlet-gazdálkodási módszerek fejlődésének ismertetése felszíni vizek vonatkozásában}

A 20. század első felében a meglévő hidrológiai módszerekre alapuló számítások voltak jellemzők a hazai vízkészlet-gazdálkodásban, nem készítettek nagy volumenü vízmérlegeket, néhány zsúfolt mezőgazdasági területnél azonban ebben az időben is szükség lehetett a vízelosztás tervezésére.

1949-től kezdve fokozatosan nőtt a vízhasználatok száma és a fajlagos vízfogyasztás is, valamint ezzel egy időben a szennyvízkibocsátás is növekedett. Ezek következményeként mennyiségi és minőségi problémák is adódtak a vizeinkben, ami indokolta a szakágazatok közötti koordinációt, valamint a vízkészlet-gazdálkodás fejlesztését [8]. Jól látható az 1. ábrán az öntözött területek nagyságának növekedése, ami magával hozta a növekvő vízigényeket is.

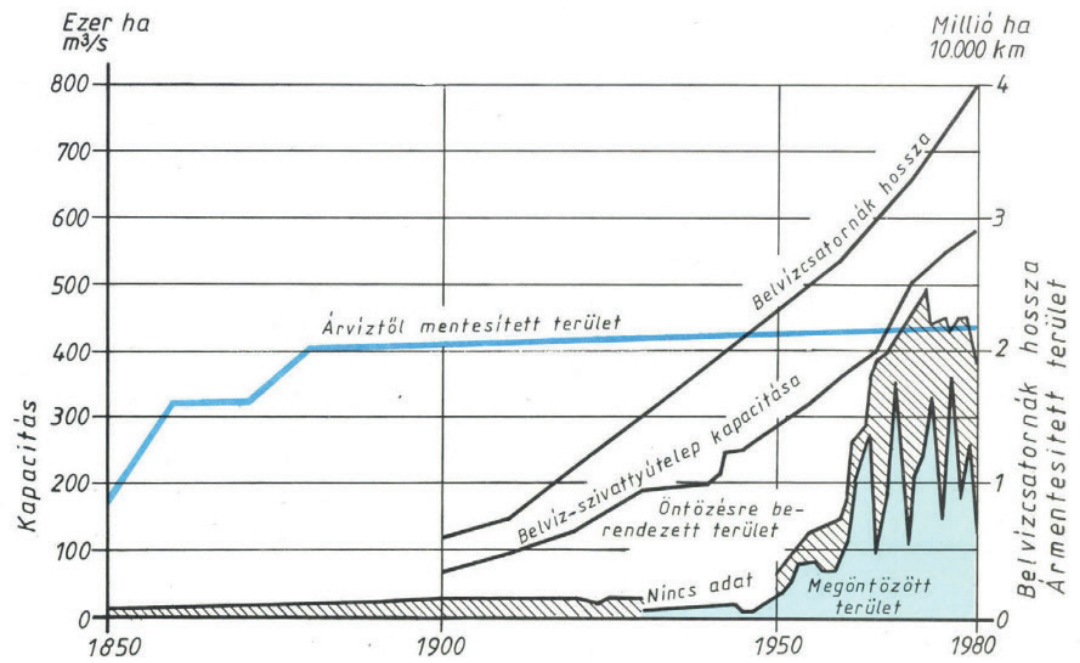

1. ábra

A vízügyi infrastruktúra alakulása Magyarországon 1980-ig [8: 231.]

Vízkészlet-gazdálkodás esetén össze kell vetni a vízigényeket az ismert készletekkel, amit szemléletesen vízmérlegek készítésével lehet elvégezni.

Ilyen vízmérleget először az 1954-es kerettervhez készítettek és ebben az időben alakult ki az a gyakorlat is, hogy a sokévi augusztusi napi $85 \%$-os és $80 \%$-os tartósságú vízhozamokat vették mértékadónak a rendelkezésre álló vízkészletek számításánál. A vízmérlegkészítés kezdeti szakaszaiban alkalmazták a szeptemberi 99\%-os tartósságot is, azonban erről kiderült, hogy nem elég finom módszer és nem mutat sehol hiányokat [8]. 1950-ben volt olyan elképzelés is, hogy az öntözési idény mértékadó készleteit számolják, azonban ez torz eredményt, több rendelkezésre álló vízkészletet adott volna a május-júniusi csapadékosabb időszak miatt [8].

Az 1960-tól kiadott Vízkészletgazdálkodási Évkönyvben vízgazdálkodási egységeknek (területileg összefüggő vízgyújiők, például Balaton, Közép-Duna stb.) határozták 
meg a hasznositható készletét az oda be- és kilépő vízhozamok különbségéböl, figyelembe véve a tározásból származó pótlást, a mederben hagyandó készletet, a szennyvízhozamokat és az esetlegesen más vízgyüjtőkről átkönyvelendő mennyiségeket.

A vízigényeket korábbi kerettervek alapján számolták, néhol pedig mért adatok vagy becslés alapján. Az öntözési és halgazdálkodási igényeket növénycsoportonkénti és területi víznormákkal vették figyelembe [7].

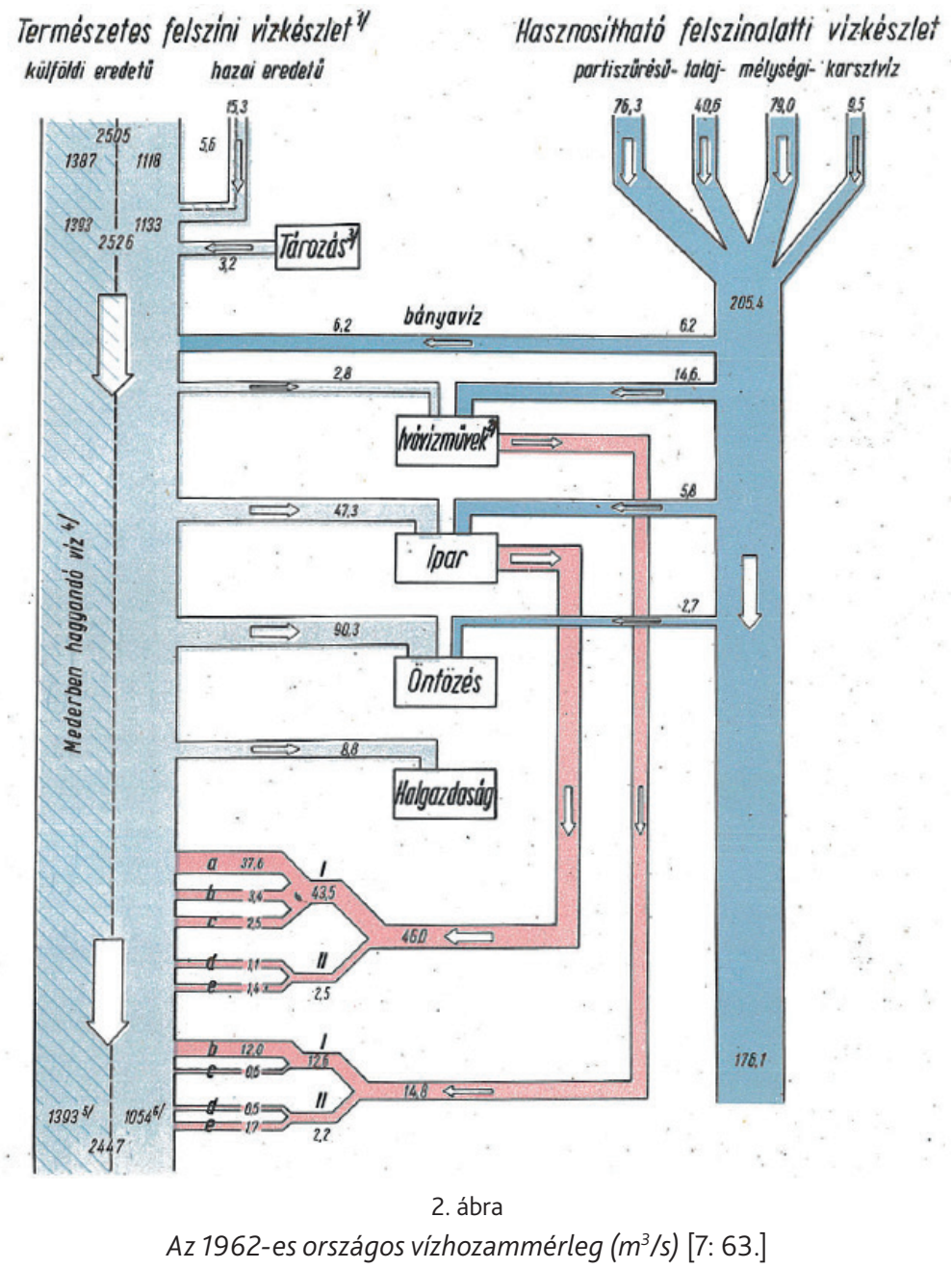

A 2. ábrán az évkönyv országos vízhozammérlege látható, amely szemléletesen kifejezi a készletek és a vízhasználatok közti kapcsolatokat is.

Az ezután kiadott vízkészletgazdálkodási évkönyvek is hasonló metodikát követtek, azonban az évek során több újítás is megjelent, például a csatornákra lebontott vízmérlegek, részletes rajzok a területi vízmérlegekről vagy szerkesztett vízgazdálkodási hossz-szelvények. 
Az 1965-ös kerettervnél az 1954-eshez hasonlóan készítették el a vízmérleget, tehát szintén a sokévi augusztusi napi $85 \%$-os és $80 \%$-os tartósságú vízhozamokat vették mértékadónak a rendelkezésre álló vízkészletek számításánál.

A vízkészlet-gazdálkodás fejlesztésére és az üzemirányítás támogatására több müszaki segédlet is megjelent az 1970-es években. Ebben az időszakban ismerték fel, hogy a szakterület fejlődése olyan mértékü, hogy egyre komplexebb problémák jelentkeznek, így az automatizálás bevezetésére is szükség lehet [9]. Olyan módszereket ismertettek a szerzők ezekben a kiadványokban, mint a különböző modellek és mátrixok alkalmazása vagy vízgazdálkodási hossz-szelvények készítése.

Az 1984-es kerettervben a korábbiakhoz hasonlóan számított vízmérleg készült, azonban új fejlesztési irányt is tartalmazott. Ennek a lényege, hogy az igényeket és készleteket három alrendszerben kellene vizsgálni, a vízkészlet, vízszolgáltató és vízhasználati alrendszerekben. Az ezek között lejátszódó folyamatok (3. ábra) figyelembevétele adhat értékelést a vízmérlegre vonatkozóan [8].

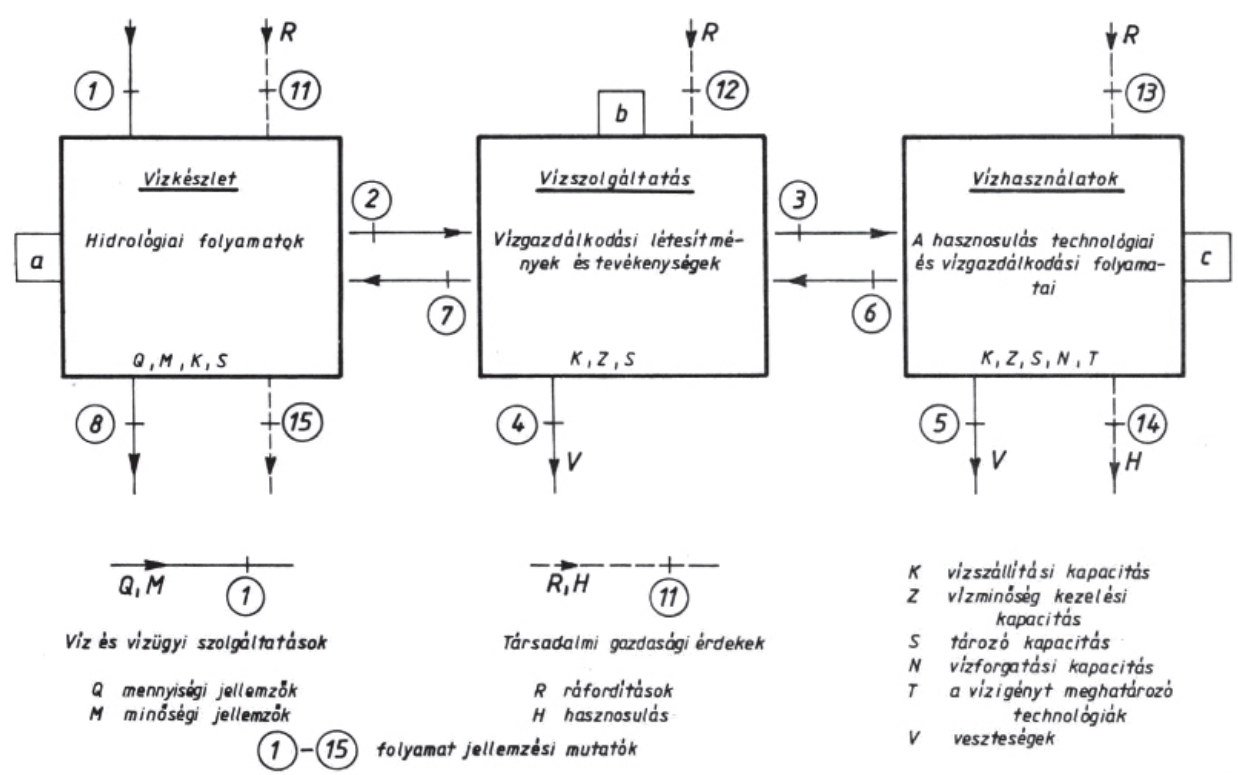

3. ábra

A vizkészlet-gazdálkodás három alrendszere [8: 260.]

A Vízkeret Irányelv, illetve az ahhoz kapcsolódó segédletek iránymutatásait követték a magyar vízgyűjtő-gazdálkodási tervek (a továbbiakban: VGT) vízmérlegei. Az 1. VGT-ben alapvetően az augusztusi 80\%-os tartósságú kisvízhozamok alapján értékelték a víztesteket hidrológiai szempontból. A kisvizes készlet számítása azért fontos, mert „a vízfolyásokban az idő túlnyomó részében a sokéves középvízhozamnál (a továbbiakban: KÖQ) kisebb lefolyást találunk: kisvízfolyásokban az év kétharmadában nem többet, mint a KÖQ 10-50\%-át. A Víz Keretirányelv szerinti jó vízállapotnak tehát elsősorban kisvízi lefolyási körülmények között kell teljesülnie. A jó ökológiai 
állapothoz mindig meg kell lennie annak a vízmennyiségnek, amely a vízi élővilág fennmaradásához szükséges, a jó kémiai állapot eléréséhez pedig a vízszállításnak elegendőnek kell lennie ahhoz, hogy a vízfolyás szennyezőanyag terhelése ne lépje túl a megengedett koncentrációkat, továbbá, hogy a vizek mennyiségi terhelése (vízkivételek, vízátvezetések) kisvízi körülmények között se haladja meg a megengedett mértéket." [10: 7.] Az ökológiai kisvizet a felszíni víztestek típusától függő arányosító szorzó adta meg (az augusztusi 80\%-os vízmennyiségeket beszorozva), míg a korábbi magyar gyakorlatban többször a 0,75-ös szorzó merült fel. A 2. VGT-ben is hasonló elvekre épülő vízmérlegszámítás készült el.

Változás a jelenleg készülő 3. VGT-nél várható a gyakorlatban. Itt a vízgyüjtőkre az Európai Bizottság Technical Report 2015-090-ja alapján, azaz a hidrológiai körfolyamat elemeit részletesen figyelembe véve [12] készülne vízmérleg, valamint gyakorlati megfontolás alapján külön vízfolyásokra is. A klasszikus statisztikai módszerek mellett valós idejü modellezés lesz a mérlegkészítés eszköze. A modellezés célja, hogy az üzemirányításban támogassa a vízügyi igazgatóságokat a pillanatnyi szabad vízkészlet meghatározásával, amivel az adott vízfolyás terhelhetőségét lehet számolni, ami pedig közvetve a távlati tervezést hivatott támogatni. Továbbá azokon a vízfolyásszakaszokon, ahol már $70 \%$ fölött van a szabad vízkészlet kiadása, a részletesebb engedély segítségével feltárható a még fel nem használt vízkészlet. Készülni fognak továbbá hidrológiai és vízkészlet-gazdálkodási hossz-szelvények az 1984-es keretterv mintájára [11].

A jelenleg érvényes 2008-as magyar jogszabály szerint a szabad vízkészleteket továbbra is a statisztikai feldolgozás alapján az augusztusi $80 \%$-os tartósságú középvízhozamokra kell meghatározni, de megenged némi eltérést is ettől.

\section{A 30/2008. (XII. 31.) KVVM rendelet 8. paragrafusa szerint:}

„(1) Felszíni vizek igénybevételének tervezésekor a vízháztartási mérleg készítésére mértékadó időszak az augusztus hónap. A mértékadó vízhozam statisztikai jellemzője a $80 \%$-os tartósságú középvízhozam, vagy, ha rendelkezésre állnak adatok, a napi középvízhozam. Rendkívüli esetben, amikor a vízigény egyéb hónapban is meghaladja ezen értéknek a 25\%-át, ettől el lehet térni azzal, hogy ebben az esetben a szűkebb mérleget mutató időszak a mértékadó.

(2) Felszíni vízkivételek, átvezetések tervezésekor a mederben hagyandó vízhozam értéke legalább a mértékadó kisvízi vízhozam kétharmada, amitöl részletes ökológiai és hidrológiai vizsgálat alapján el lehet térni. A mértékadó vízhozam számításánál figyelembe kell venni az aktuális hidrológiai alapadatokat, a tározási lehetőségeket és a vízjogi állapotot"[13].

\section{Következtetések}

A hazai vízkészlet-gazdálkodás a 20. század második felében komoly változásokon ment keresztül, azonban néhány alapvető eljárás a kezdetektől ugyanaz maradt. A módszerek fejlődését az 1. táblázatban bemutatott korszakokra tudtam beosztani: 
1. táblázat

A vízkészlet-gazdálkodás korszakai Magyarországon [a szerző szerkesztése]

\begin{tabular}{|l|l|}
\hline időszak & leírás \\
\hline 1949 előtt & nem jellemző vízmérlegek készítése, helyi vízkészlet-gazdálkodás \\
\hline $1949-1960$ & az igények növekedésével egyre több helyi és átfogó vízmérleg, távlati tervek \\
\hline $1960-1984$ & $\begin{array}{l}\text { vízkészlet-gazdálkodási évkönyvek, müszaki segédletek, távlati koncepciók } \\
\text { kidolgozása }\end{array}$ \\
\hline $1984-2000$ & az 1984-es keretterv utáni időszak jelentősebb újdonság nélkül \\
\hline 2000-napjainkig & a VKI ajánlásai alapján elvégzett feladatok \\
\hline napjainktól- & a vízkészlet-gazdálkodás modellezéssel történő fejlesztése \\
\hline
\end{tabular}

Általánosságban elmondható, hogy a vízkészlet-gazdálkodási szakág legnagyobb ütemű fejlődése az 1950-1970-es évekre tehető, amikor a legtöbb újdonság született meg a témában. Az 1980-as évektől a Víz Keretirányelv megjelenéséig stagnáló időszak volt jellemzö, nem jelentek meg jelentős módszertani változások. A VKI azonban szemléletében különbözött a korábbi hozzáállástól a víztestek minőségének, ökológiai állapotának előtérbe helyezése miatt. Korábban is értékelték a vízkészletek minőségét Magyarországon (például az évkönyvekben vagy a kerettervekben), azonban ez egyenrangú volt a mennyiségi értékeléssel. A vízgyűjtő-gazdálkodási tervekben jól szemlélteti az alábbi ábra a mennyiségi értékelés szerepét.

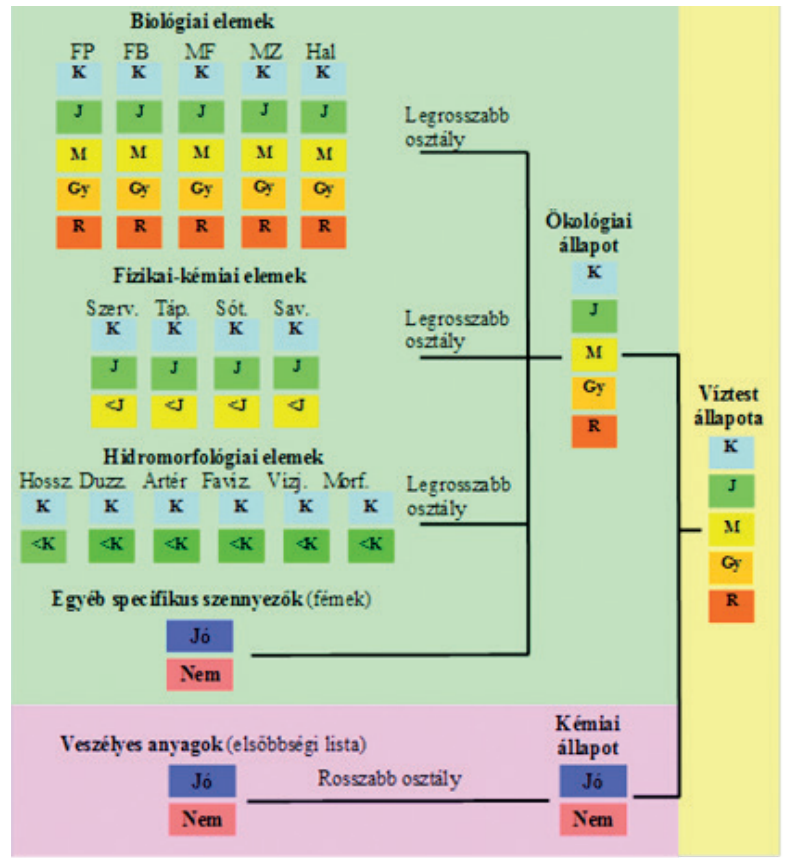

4. ábra

A felszíni vizekre vonatkozó minősitési rendszer sémája [14] 
A mennyiségi értékelés a hidromorfológiai értékelés egyik eleme és legrosszabb esetben is csak jó besorolási kategóriába ronthatja az állapotot az ötös skálán, tehát főként következtetéseket lehet levonni ebböl, nem befolyásolja érdemben az állapotértékelést.

Napjainkban felismerték a szakemberek, hogy az éghajlatváltozás és a tervezett öntözési fejlesztések miatt újra fontosabb szerepet kell szánni a vízkészletek mennyiségi értékelésének és új metodikák kidolgozásának. Ezt a számítógépes hidrodinamikai és hidrológiai modellek (HecRAS, HecHMS) használatával, valamint módszertani fejlesztésekkel érnék el.

Véleményem szerint ez mindenképpen szükséges, ugyanis a korábbi gyakorlatok más rendszerben és környezetben alakultak ki, a technológia fejlödésével pedig új utakat lehet igénybe venni.

A hazai szakemberek szerint Európában vízhiányok miatti korlátozások és a szokatlan szélsőséges állapotok is egyre gyakrabban előfordulhatnak a következő évtizedekben [15], ezért feltehetően nőni fog az igény a hatékony vízkészlet-gazdálkodásra. Lényeges lehet ezzel kapcsolatban az országhatárral osztott vízgyűjtők határvízi egyeztetésein kialakított közös vízkészletszámítási metodikák kidolgozása, megkönnyítve az érintett országok közti vízkészlet-gazdálkodással kapcsolatos megállapodások megkötését.

Az embereknek egyre fontosabb lesz a környezetükben lévő vízkészletek pontos ismerete, és az információs technológiák fejlődése is megkívánja az adatok egyszerü elérésének lehetőségét, így a jövő mindenképpen egy olyan digitális platform lehet, ahol az emberek megtehetik ezt. Példaként említhető az úgynevezett Danube GIS honlap [16], ahol a Duna-vízgyüjtő vizekkel és élőhelyekkel kapcsolatos mérési eredményei és az ezek állapotát befolyásoló különböző hatások jeleníthetők meg, bárki által elérhető, átlátható, térképes formátumban.

Egy ilyen platform mögé természetesen szakszerü módszertan és hatalmas adatbázis szükséges, de a vízügyi ágazatnak célja az ilyen irányú fejlödés elérése a közeljövőben. A fejlődés kényszere miatt várható továbbá, hogy az 1970-es évekhez hasonlóan egyre több szakirodalom szülessen a felszíni és felszín alatti vízkészlet-gazdálkodás témájában, továbbá a jogszabályi környezetet is felülvizsgálhatják.

\section{Hivatkozások}

[1] Közép-Duna-völgyi Vízügyi Igazgatóság, „Történelmi áttekintés," Közép-Dunavölgyi Vízügyi lgazgatóság, [Online]. Elérhető: www.kdvvizig.hu/index.php/rolunk/ vizugy-tortenete (Letöltve: 2019. 02. 14.)

[2] D. Bőzsöny és M. Domokos, A vízkészletgazdálkodás alapjai és a vízgazdálkodási mérleg. Budapest: Tankönyvkiadó, 1975.

[3] OVF Vízügyi Tervező Vállalat, Közép-Tisza és Mátravidék Vízgazdálkodási Keretterve. Budapest: OVF Vízügyi Tervező Vállalat, 1965.

[4] Magyar Hidrológiai Társaság, „Sajó Elemér életrajza,” Magyar Hidrológiai Társaság, [Online]. Elérhető: www.hidrologia.hu/mht/index.php?option=com_content\&task=view\&id=226\&ltemid=143 (Letöltve: 2019. 02. 14.) 
[5] I. Láng, „A vízkészlet-gazdálkodás megújítása," XXXIV. Országos Vándorgyűlés, július 6-8, 2016, Debrecen, Hungary [Online]. Elérhető: www.hidrologia.hu/vandorgyules/34/dolgozatok/word/0108_lang_istvan.pdf (Letöltve: 2019. 03. 06.)

[6] Directive 2000/60/EC of the European Parliament and of the Council establishing a framework for the Community action in the field of water policy, [Online]. Elérhető: https://eur-lex.europa.eu/legal-content/en/ALL/?uri=CELEX:32000L0060 (Letöltve: 2019. 03. 06.)

[7] Vízgazdálkodási Tudományos Kutató Intézet, Vízkészletgazdálkodási Évkönyv 1962. Budapest: Vízgazdálkodási Tudományos Kutató Intézet, 1963.

[8] Vízgazdálkodási Intézet, Országos Vízgazdálkodási Keretterv. Budapest: Országos Vízügyi Hivatal, 1984.

[9] M. Domokos, Vízkészletgazdálkodási rendszerek modellezése. Budapest: Vízügyi Dokumentációs és Tájékoztató Iroda, 1975.

[10] M. Szalay, A felszíni vizek mennyiségi jellemzése: kisvízi készlet. Budapest: ÖKO Zrt. vezette konzorcium, 2009.

[11] VITUKI Hungary Kft., A felszíni tervezési egységekre a vizkészlet-gazdálkodás számitásainak, jellemzőinek, táblázatainak, térképeinek és modelljeinek elkészitése az ország területére Zagyva modellterület. Budapest: VITUKI Hungary Kft., 2018.

[12] European Commission, "Guidance document on the application of water balances for supporting the implementation of the WFD," Luxembourg, Office for Official Publications of the European Communities, Technical Report-2015-090, 2015. DOI: https://doi.org/10.2779/352735

[13] 30/2008. (XII. 31.) KvVM rendelet a vizek hasznosítását, védelmét és kártételeinek elhárítását szolgáló tevékenységekre és létesítményekre vonatkozó műszaki szabályokról [Online]. Elérhető: http://njt.hu/cgi_bin/njt_doc.cgi?docid=117437.362753 (Letöltve: 2019. 08. 06.)

[14] Országos Vízügyi Főigazgatóság, A Duna-vízgyüjtő magyarországi része Vízgyüjtőgazdálkodási Terv. Budapest: Országos Vízügyi Főigazgatóság, 2015.

[15] I. Ijjas, L. Somlyódy és J. Józsa, „Vízbiztonság Európában, a Duna vízgyűjtőjén és Magyarországon" in Biztonsági kihívások a 21. században, G. Finszter és I. Sabjanics, szerk. Budapest: Dialóg Campus, 2017, pp. 423-462.

[16] ICPDR, „About the DanubeGIS,” danubegis.org, [Online]. Elérhető: www.danubegis.org/about (Letöltve: 2019. 08. 14.) 